\title{
CRYSTALLIZATION AGES AND GEOCHEMISTRY OF THE MINERS BAY AND CEDAR BAY PLUTONS, PRINCE WILLIAM SOUND, ALASKA
}

VICTOR R. GARCIA JR., The University of Texas at Austin

Research Advisor: Daniel F. Stockli

\section{INTRODUCTION}

The Late Eocene Eshamy Suite plutons (ESP) intrude turbidites of the Chugach-Prince William (CPW) terrane in western Prince William Sound. The Prince William Sound region of South-Central Alaska consists of the Chugach-Prince William Terrance (CPW), containing the Valdez and Orca Group separated by the Contact fault. The Valdez Group is Late Cretaceous in age and is characterized by a thick sequence of interbedded siltstone, greywacke, and pebble conglomerate likely deposited as turbidites on submarine fans (Tysdal and Plafker, 1978). South of the Valdez is the Orca Group of Paleocene to Eocene age, characterized by folded and faulted rocks that have been intruded by younger plutons (Davidson and Garver, 2017). The CPW has been traditionally interpreted as a Late Cretaceous to Paleocene accretionary wedge complex that was either formed in situ or was deposited farther south and subsequently transported a significant distance along the continental margin (cf. Cowan, 2003; Haeussler et al., 2003).

The ESP is a bimodal suite of granites dominated by biotite granites and leucogranites with subordinate gabbro. Questions for the ESP include the crystallization ages for the plutons, their relationship to igneous rocks found farther inboard, and the nature of the tectonic setting. For this study, we examined a set of granites from Miners Bay and Cedar Bay to compare with the rocks from the Nellie Juan and Eshamy Bay plutons to the southwest (Fig. 1), and the Caribou Creek volcanics (CCV) that occur $200 \mathrm{~km}$ inland. Our results show that the Miners and Cedar Bay plutons fall within the age range of the CCV and are marginally older than the Nellie Juan (NJP) and Eshamy Bay plutons (EBP) (Cole et al., 2006; Johnson, 2012). However, preliminary geochemical data suggest that the ESP may not be directly related to the CCV and therefore may have formed in a different tectonic setting.

\section{FIELD AND PETROGRAPHIC DESCRIPTIONS}

This study focuses on the Miners Bay diorite and leucogranite which intrude the Valdez turbidites, and the Cedar Bay pluton which intrudes the Orca Group in Prince William Sound (Fig. 1). The Miners Bay diorite is truncated along its southern margin by the Miners Bay fault and the Miners Bay leucogranite occurs as a small intrusive body along the northern margin of the diorite (Fig. 1B). The diorite is black and white, equigranular hypidiomorphic containing plagioclase, clinopyroxene, and hornblende with minor biotite and ilmenite (Fig. 2A). The Miners Bay leucogranite is white, equigranular hypidiomorphic containing plagioclase, perthitic orthoclase, and quartz with trace biotite (Fig. 2B). The Cedar Bay pluton is dominated by light grey leucogranite with rare mafic enclaves and crops out south of Miners Bay (Fig. 1B). It is primarily equigranular hypidiomorphic containing plagioclase, orthoclase and quartz with trace biotite. In most samples the feldspars are partially to completely replaced by fine grained sericite and epidote (Fig. 2C).

\section{ANALYTICAL METHODS \& RESULTS}

Fourteen whole-rock samples from the Miners Bay and Cedar Bay plutons including three mafic enclaves 

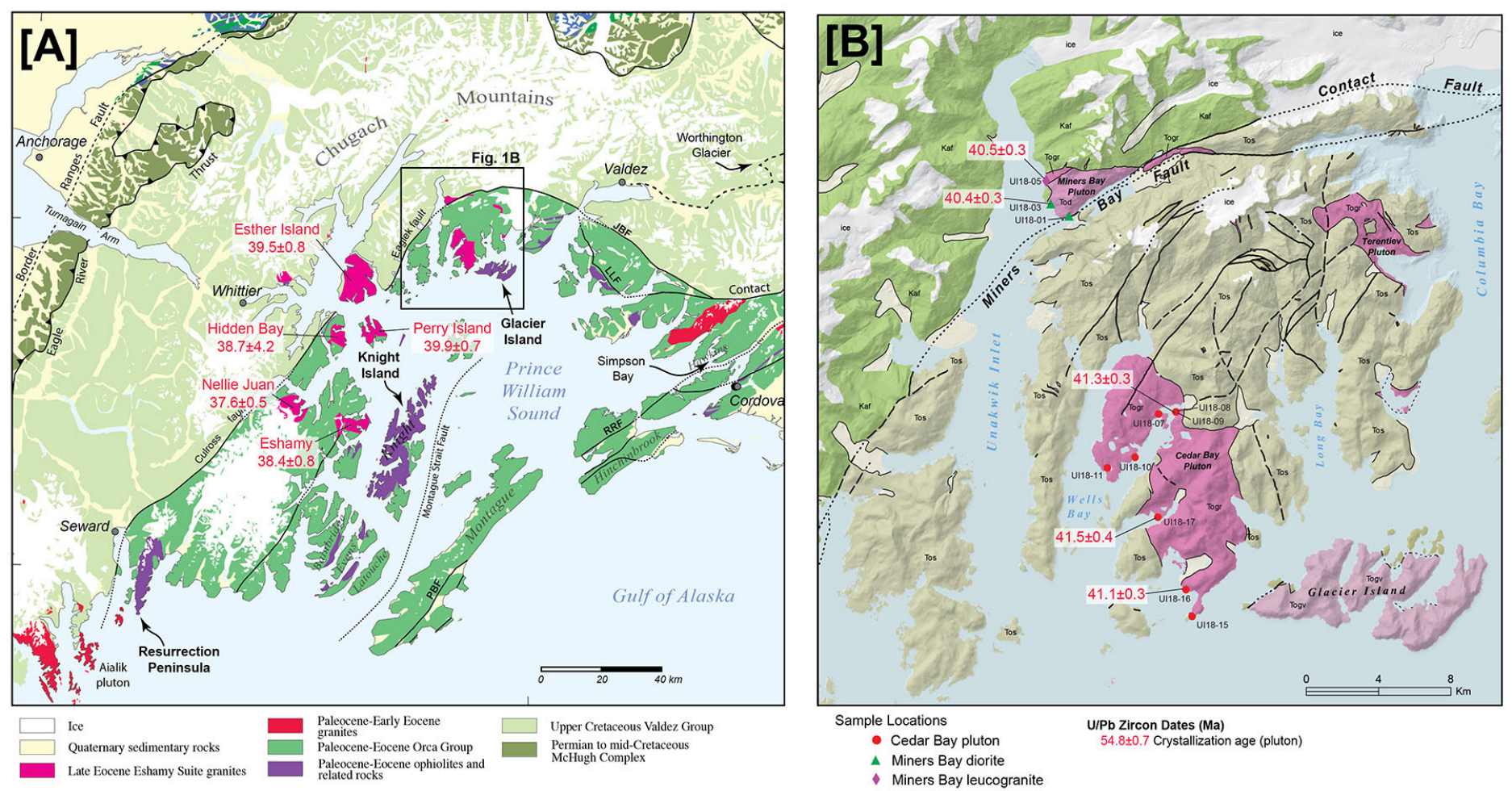

Figure 1. A) Geologic map of the CPW terrane (modified from Bradley et al., 2003). U/Pb ages of the Eshamy Suite plutons from Davidson and Garver (2017) and this study. Box shows approximate location of Fig. 1B. B) Geologic Map of northern Prince William Sound showing the Miners Bay and Cedar Bay plutons (modified from Wilson et al., 2015).

were analyzed at the Hamilton Analytical Laboratory using XRF for major elements and LA-ICP-MS for trace elements. In addition, zircon from the Miners Bay diorite (UI18-03), leucogranite (UI18-05), and from three samples from the Cedar Bay pluton (UI18$09,16,17)$ were extracted and $\mathrm{U} / \mathrm{Pb}$ dated using LA-ICP-MS at the University of Arizona Laserchron Center. Approximately 35 zircons were analyzed for each sample, and BSE and CL images were used to discriminate between inherited cores (rare) and magmatic rims.

\section{Geochemistry}

The Miners Bay diorite contains $\sim 53 \mathrm{wt} \% \mathrm{SiO} 2$ and plots as a gabbroic diorite on a plutonic TAS classification diagram (Fig. 3A). The Miners Bay leucogranite and all host-rock samples from the Cedar Bay pluton contain $72-77 \mathrm{wt} \% \mathrm{SiO} 2$ and plot in the granite field, and the three mafic enclaves contain 66$72 \mathrm{wt} \% \mathrm{SiO}$. All samples are calc-alkalic to calcic on the modified alkali index of Frost (2008) and are magnesian with the exception of the leucogranite and mafic enclave from the Miners Bay leucogranite which plot in the ferroan field (Fig. 3). All of the rocks are peraluminous except for the Miners Bay diorite, the enclave from the Miners Bay leucogranite, and two samples from the Cedar Bay pluton (UI1815\&17; Fig. 3C).

Selected trace elements in the Miners Bay and Cedar Bay plutons are shown in Figure 4. REE concentrations from the Cedar Bay leucogranites and their xenoliths and the Miners Bay leucogranite are remarkably similar and are enriched in the LREE's and show a pronounced negative Eu anomaly (Fig. 4A). The xenolith from the Miners Bay leucogranite is enriched in HREE's relative to its host, has a pronounced negative Eu anomaly, and is slightly depleted in the LREE's compared to the HREE's. The Miners Bay diorite had a flatter REE profile, is depleted relative to the granites, and shows a small positive Eu anomaly relative to chondrites. All samples have low $\mathrm{Sr} / \mathrm{Y}$ ratios except for the Miners Bay diorite which has low Y and high Sr/Y ratios (Fig. 4B).

\section{U/Pb Geochronology and Hf Isotope Geochemistry}

The weighted mean ages of the five samples dated 

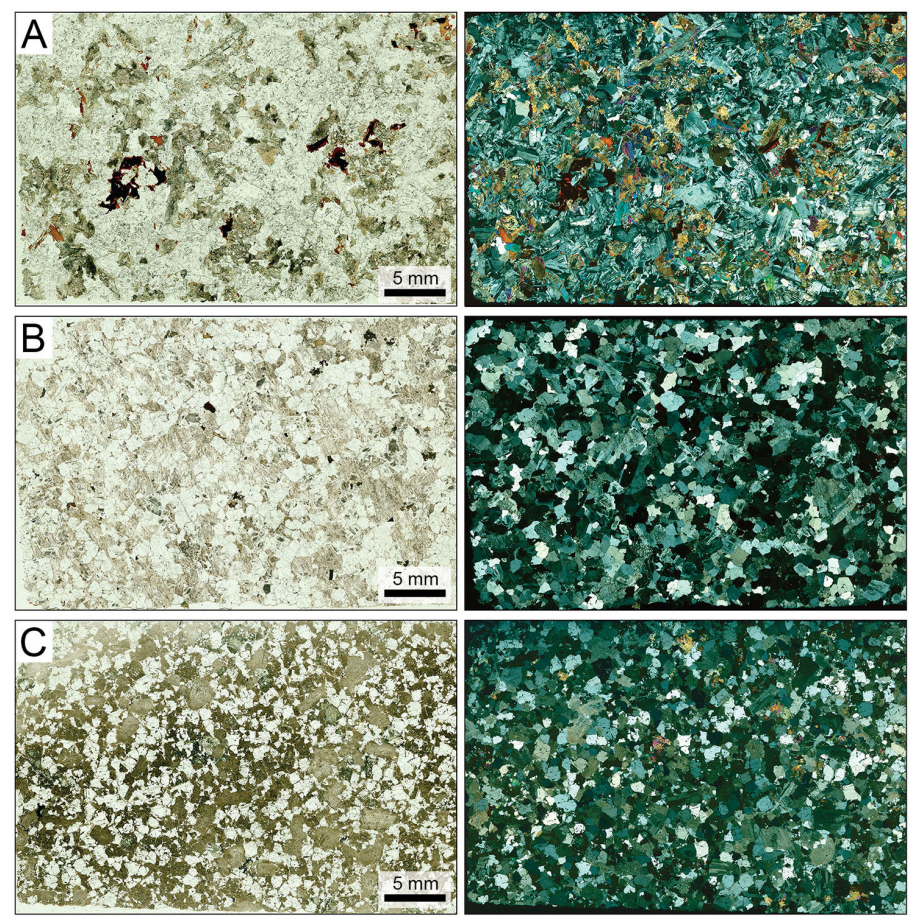

Figure 2. Photomicrographs (PPL and XPL) from the Miners Bay and Cedar Bay plutons. A) Miners Bay diorite (UI18-03). B) Miners Bay leucogranite (UI18-05A). C) Cedar Bay leucogranite (UI18-16) showing near complete replacement of feldspars with sericite and fine-grained epidote. High interference colors in XPL are coarse-grained (secondary) epidote.

in this study are shown in Table 1. The Miners Bay diorite (UI18-03) and leucogranite (UI18-05A) yielded ages of $40.41 \pm 0.32 \mathrm{Ma}$ and $40.45 \pm 0.36$ Ma, respectively. Cedar Bay pluton samples (UI18$09,16,17)$ yielded ages of $41.27 \pm 0.37 \mathrm{Ma}, 41.53 \pm$ $0.35 \mathrm{Ma}$, and $41.06 \pm 0.37 \mathrm{Ma}$, respectively. Most of the samples show no inheritance with the exception of a 61.5 Ma zircon in the Miners Bay leucogranite. Zircons from the Miners Bay diorite (UI18-03), leucogranite (UI18-05A), and Cedar Bay leucogranite (UI18-16) were also analyzed for Hf isotope ratios (Fig. 4; Table 1). Most zircons yield juvenile signatures $(\varepsilon \mathrm{Hf} \sim+4$ to +10$)$, but the Miners Bay leucogranite contains zircon with $\mathrm{EHf}$ as low as -14.7 (Fig. 4).

\section{DISCUSSION}

The Miners Bay and Cedar Bay leucogranites are aluminum-rich, calc-alkalic to calcic plutonic rocks and appear to be similar to the Eshamy and Nellie Juan plutons of the Eshamy suite that crop out to the southwest (Figs. 1\&3). However, the leucogranites have fewer mafic minerals and appear to be more
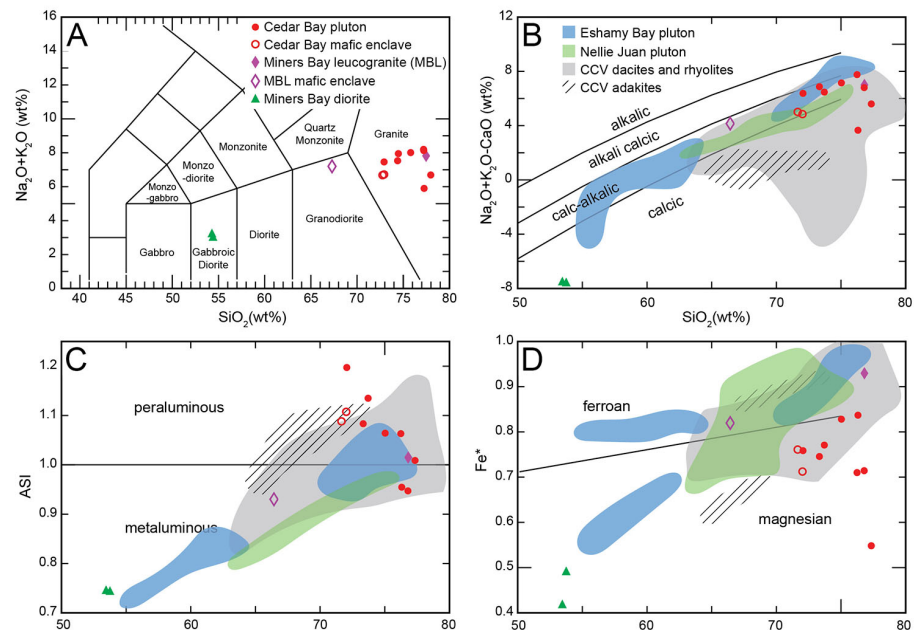

Figure 3. Major element geochemistry of the Miners Bay and Cedar Bay plutons. A) TAS classification for plutonic rocks (Middlemost, 1994). B) Modified alkali-lime index, C) aluminumsaturation index (ASI), and D) Fe index from Frost and Frost (2008). Data for the Eshamy Bay and Nellie Juan plutons from Johnson (2012) and data from the Caribou Creek volcanics (CCV) from Cole et al. (2006).

magnesian than the rest of the Eshamy suite (Fig. 3D).

The ESP are similar to the CCV in terms of major elements. While samples from the Miners Bay and Cedar Bay pluton are magnesian, most of the ESP is ferroan (Fig. 3D). Although some of the CCV plots onto the magnesian field, most of the CCV samples are ferroan aligning with the ESP. The EBP/ NJP and $\mathrm{CCV}$ also plot in the metaluminous field along with some of the Miners Bay and Cedar Bay pluton plotting in the peraluminous field (Fig. 3C).

The negative Eu anomaly associated with samples from the Miners Bay and Cedar Bay pluton suggests that plagioclase is fractionating from the melt, whereas a positive anomaly suggests plagioclase accumulation. The REE signatures from the dacites and rhyolites of the CCV are similar to the ESP which both share a negative Eu anomaly, but with just a flatter profile and slightly enriched HREEs (Fig. 4A). The Miners Bay diorite has a positive anomaly indicating the possibility that these are the cumulates of the Miners Bay leucogranites. The MB diorite also compares to the CCV in terms of REE's and $\mathrm{Sr} / \mathrm{Y}$ ratio, indicating that these diorites may have undergone the same magmatic processes or come from a similar source region (Fig. 4B).

Previously sampled granitoid intrusions from the EBP and NJP were emplaced between $37.6 \pm 0.5$ and 39.9 

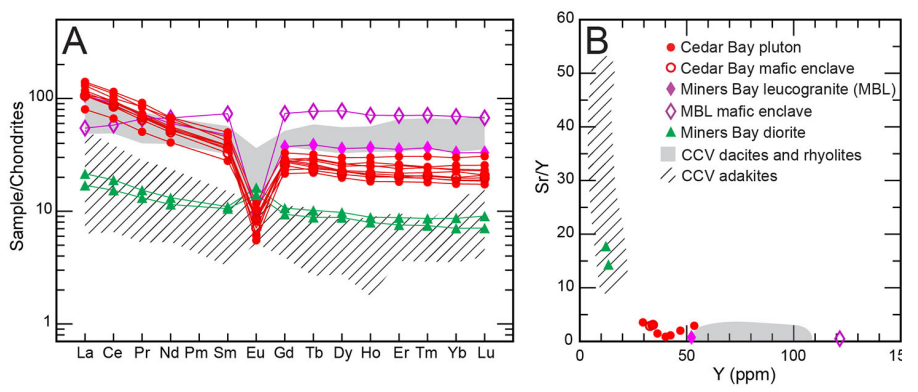

Figure 4. Trace element geochemistry of the Miners Bay and Cedar Bay plutons. A) REE's normalized to chrondrites (Sun and McDonough, 1989). B) Sr-Y diagram. Data for the Caribou Creek volcanics (CCV) from Cole et al. (2006).

$\pm 0.7 \mathrm{Ma}$ (Johnson, 2012). The age range of 40.41 $\pm 0.32 \mathrm{Ma}$ to $41.53 \pm 0.35 \mathrm{Ma}$ of the Miners Bay and Cedar Bay plutons confirm that they are part of the Eshamy Suite and also suggests an eastward age progression. In addition, a sandstone sample in UI18$12 \mathrm{~A}$ in the Orca Group on Outpost Island (south of Unakwik Inlet) has an age of $40.9 \pm 0.7$ Ma suggesting it formed at the same time as the Eshamy Suite plutons and deposition occurred during intrusion. The CCV ranges from 52 to $36 \mathrm{Ma}$ and fall within the age range of the ESP however may differ in source region and tectonic environment as they are located $200 \mathrm{~km}$ to the north of the ESP (Fig. 1; Cole et al., 2006). The Miners Bay and Cedar Bay plutons share a mostly juvenile Hf signature with the EBP and NJP however,

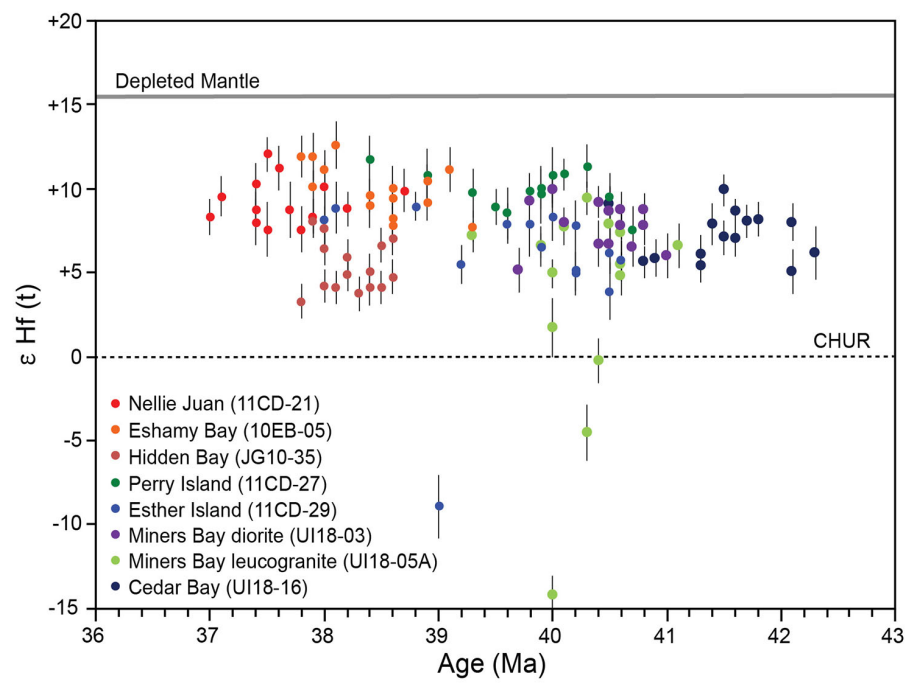

Figure 5. Zircon \&Hf vs U/Pb age from the Eshamy Suite plutons (Fig. 1). Most zircons have a juvenile signature; however, the Esther Island pluton and Miners Bay leucogranite have negative ¿Hf values suggesting the incorporation of more evolved crustal material in the source region.

\begin{tabular}{|c|c|c|c|c|c|c|c|c|c|}
\hline Sample & Location & Latitude & Longitude & $\begin{array}{l}\text { U/Pb } \\
\text { Age } \\
\text { (Ma) }\end{array}$ & \pm & MWSD & $\begin{array}{c}\begin{array}{c}\text { No. of } \\
\text { zircons } \\
\text { analyzed }\end{array} \\
\end{array}$ & $\begin{array}{l}\text { Mean } \\
\varepsilon \mathrm{Hf}\end{array}$ & \pm \\
\hline $\begin{array}{l}\text { Ul18-03 } \\
\text { (gabbroic } \\
\text { diorite) }\end{array}$ & $\begin{array}{l}\text { Head of } \\
\text { Miners Bay }\end{array}$ & 61.0773 & -147.5052 & 40.41 & 0.32 & 1.4 & 34 & +8.0 & 0.6 \\
\hline $\begin{array}{l}\text { Ul18-05A } \\
\text { (granite) }\end{array}$ & Miners Bay & 61.0887 & -147.5089 & 40.45 & 0.33 & 1.8 & 32 & +4.7 & 0.6 \\
\hline $\begin{array}{l}\text { Ul18-09 } \\
\text { (granite) }\end{array}$ & Cedar Bay & 60.5827 & -147.2340 & 41.27 & 0.33 & 1.9 & 33 & N/A & $N / A$ \\
\hline $\begin{array}{l}\text { Ul18-16 } \\
\text { (granite) }\end{array}$ & $\begin{array}{c}\text { Cedar Bay } \\
\text { (Fairmont } \\
\text { Bay) }\end{array}$ & 60.8876 & -147.3836 & 41.53 & 0.35 & 0.99 & 30 & +7.4 & 0.5 \\
\hline $\begin{array}{l}\text { Ul18-17 } \\
\text { (granite) }\end{array}$ & $\begin{array}{c}\text { Cedar Bay } \\
\text { (Granite } \\
\text { Bay) }\end{array}$ & 60.9233 & -147.4008 & 41.06 & 0.33 & 1.8 & 26 & N/A & $\mathrm{N} / \mathrm{A}$ \\
\hline
\end{tabular}

two samples from the Miners Bay pluton have a zircons with distinctly negative values suggesting that the source region for some of the plutons must involve partial melting and an incorporation of evolved crustal material (Fig 5).

\section{CONCLUSIONS}

The Miners Bay and Cedar Bay plutons are part of the Eshamy suite based on age and geochemistry. Although the CCV and ESP are similar by being ferroan and having comparable REE signatures, they differ by being primarily calcic and metaluminous with a high $\mathrm{Sr} / \mathrm{Y}$ ratio in the $\mathrm{CCV}$ adakites. A similar tectonic environment may attribute to a possible linkage between the CCV and ESP, but it is unclear if they come from the same magmatic system and origin.

\section{ACKNOWLEDGEMENTS}

The material from this study is based upon work supported by the National Science Foundation (NSF) under Grant No. EAR 1727991 (to C. Davidson, Carleton College), Grant No. EAR 1728013 (to J.I. Garver, Union College), and by Keck Geology Consortium Grant No. EAR 1659322 (to J.I. Garver, Union College). I would also like to acknowledge Keck Member schools, Exxon Mobil, and the University of Arizona LaserChron Center and NSFEAR Grant No. 1649254 (to M. Pecha and G. Gehrels) who made zircon analysis possible. I appreciate the Park Service permitting us access and permits to collect samples in the Chugach National Forest. Special thanks to Cameron Davidson, John Garver, and Daniel F. Stockli on their support in the lab and writing process as well as direction and advice 
throughout this project. Lastly, I would like to thank Nick Gross Almonte, Alysala Malik, Mollie Pope, Caitlin Noseworthy, and Will Fisher for their unfailing support throughout this journey.

\section{REFERENCES}

Cole, R.B., Nelson, S.W., Layer, P.W., and Oswald, P.J., 2006, Eocene volcanism above a depleted mantle slab window in southern Alaska: Bulletin of the Geological Society of America, v. 118, p. 140-158, doi:10.1130/B25658.1.

Cowan, D.S., 2003, Revisiting the Baranof-Leech River hypothesis for early Tertiary coastwise transport of the Chugach-Prince William terrane: Earth and Planetary Science Letters, v. 213, p. 463-475, doi:10.1016/S0012-821X(03)00300-5.

Davidson, C., and Garver, J.I., 2017, Age and Origin of the Resurrection Ophiolite and Associated Turbidites of the Chugach-Prince William Terrane, Kenai Peninsula, Alaska: The Journal of Geology, v. 125, p. 681-700, doi:10.1086/693926.

Haeussler, P.J., Bradley, D.C., Wells, R.E., and Miller, M.L., 2003, Life and death of the resurrection plate: Evidence for its existence and subduction in the northeastern Pacific in Paleocene-Eocene time: Bulletin of the Geological Society of America, v. 115, p. 867-880, doi:10.1130/00167606(2003)115<0867:LADOTR>2.0.CO;2.

Johnson, E., 2012, Origin of the Late Eocene Eshamy Suite granitoids in Western Prince William Sound, Alaska: 25th Annual Keck Symposium: 2012, p. 33-39.

Sun, S. S. and McDonough, W. F., 1989, Chemical and isotopic systematics of oceanic basalts; implications for mantle composition and processes (in Magmatism in the ocean basins), Geological Society Special Publications, vol. 42 p. 313-345.

Tysdal, R.G., and Plafker, G., 1978, Age and continuity of the Valdez Group, southern Alaska, in Changes in Stratigraphic Nomenclature by the U.S. Geological Survey, 1977: Geological Survey Bulletin 1457-A, v. 1422-A, p. A120-A132. 